\title{
Role of the Allahyarlu ophiolite in the tectonic evolution of NW Iran and adjacent areas (Late Carboniferous - Recent)
}

\author{
Majid Sudi Ajirlu* and Mohssen Moazzen \\ Department of Earth Sciences, University of Tabriz, 51664, Tabriz, Iran
}

\begin{abstract}
In this paper we reconstruct the tectonic evolution of Eastern Turkey, the Lesser Caucasus and NW-N Iran from the Late Carboniferous to Recent. NW Iran is one of the most complicated regions of the country, that with Turkey and the Lesser Caucasus is influenced by movements of the Arabian Plate. The Ahar Block, which is bounded by the Tabriz, Talysh, Araks, Myaneh and Allahyarlu-Hovai Faults, underwent compression and faulting. The block shows counterclockwise rotation through the confining faults and is being compressed by northward pressure from the Arabian Plate. The age and the nature of the Allahyarlu ophiolite, which is located at the northern boundary of the Ahar Block, are not known unequivocally. During the Late Carboniferous the Allahyarlu-Kaleybar-Northern Iran Basin opened, and Neotethys 1 was spreading. During the Permian the Allahyarlu-Kaleybar-Northern Iran Basin changed from a passive to a convergent environment and closed at Late Triassic to Early Jurassic time. In the Early Jurassic Neotethys 1 began to be subducted, causing the opening of the Sevan-Akera back-arc basin. Thereafter the Sevan-Akera Basin and the Neotethys 2 Basin were widening up to the Late Jurassic. The Black Sea-South Caspian Sea-Kopet Dagh Basin opened during the Jurassic. These basins were widening up to the Paleocene, but northward slider replacement of NW Iran caused the separation of the Caspian Sea Basin and the Black Sea Basin and the formation of the Kurdamir Uplift. In the Late Cretaceous the Central Iran basins were closed and the inner-Iran ophiolites were emplaced. Neotethys 1 closed in the Late Cretaceous and Neotethys 2 in the Late Miocene.
\end{abstract}

Key words: Arabian Plate, Neotethys, Ahar block, Allahyarlu ophiolite

\footnotetext{
* Corresponding author; Tabriz University, Tabriz, Eastern Azerbaijan, Iran; E-mail: majid.sudi@gmail.com

Received: January 25, 2014; accepted: August 5, 2014
} 


\section{Introduction}

There are various hypotheses discussing the genesis and evolution of NW Iran and the Lesser Caucasus (Fig. 1) (e.g. Berberian et al. 1981; Majidi 1981; Sengör 1990; Alavi 1991a; Babakhani and Nazer 1991; Eftekharnejad and Asadian 1992; Golonka 2004; Kazmin and Tikhonova 2006; Galoyan et al. 2009; Sosson et al. 2010; Rolland et al. 2011; Sheikholeslami and Kouhpeyma 2012). Here we discuss the evolution of NW Iran and the Lesser Caucasus using new evidence obtained from studies of the Allahyarlu ophiolite. NW Iran and the Lesser Caucasus together formed a region for which, despite many expressed opinions, there is no general consensus about its evolution history. In Ardebil Province of NW Iran there is an anticline called the Allahyarlu Anticline (Babakhani and Nazer 1991; Eftekharnejad and Asadian 1992; Barzegar and Pourkermani 2010; Sudi Ajirlu and Jahangiri 2010a). This anticline, of a general east-west trend, is located between the Moghan plain to the north and the Meshkinshahr plain to the south (Sudi Ajirlu et al. 2010b). The Allahyarlu ophiolite mélange is exposed along the Allahyarlu-Hovai Fault and the Allahyarlu anticline core (Barzegar and Pourkermani 2010; Sudi Ajirlu and Jahangiri 2010a). The field studies which provide the reconstruction of the geologic evolution of these regions are concentrated on the Allahyarlu ophiolite mélange. Ophiolite components such as

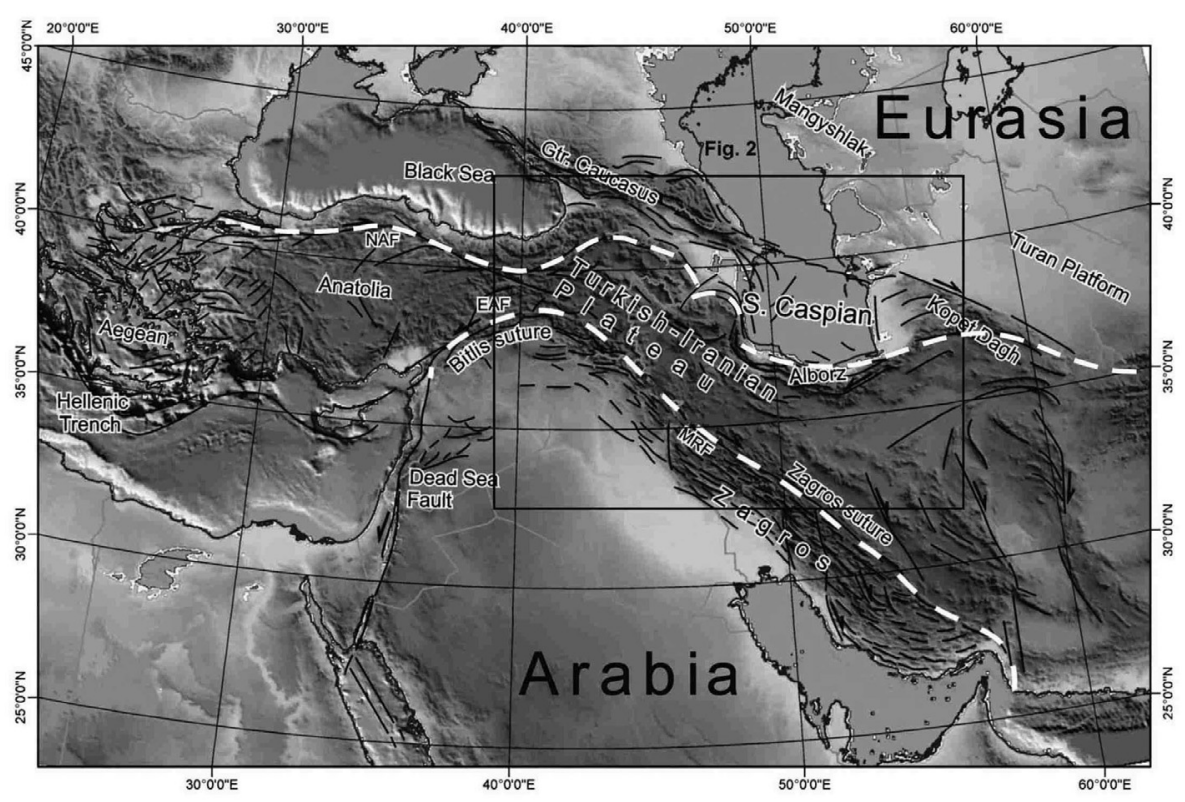

Fig. 1

Topography and regional structures map of the Arabia- Eurasia collision (after Allen et al. 2003). Main elements of the Alpine belt in this map: Turkish-Iranian plateau; Arabian platform; Greater Caucasus; Lesser Caucasus; NAF (North Anatolian Fault); EAF (East Anatolian Fault); MRF (Main Recent Fault) 
peridotite, dunite, gabbro, basalt and diabase are mixed together in the Allahyarlu ophiolite mélange. All these rock units underwent metamorphism in the greenschist facies. The Allahyarlu-Hovai fault activity resulted in the uplifting of the ophiolite mélange (Barzegar and Pourkermani 2010; Sudi Ajirlu and Jahangiri 2010a).

\section{Geologic background}

NW Iran is one of the most complicated regions within the region of the Iranian crust; there are numerous and sometimes diverse opinions on its geologic evolution (e.g. Berberian et al. 1981; Majidi 1981; Sengör 1990; Alavi 1991a; Eftekharnejad and Asadian 1992; Golonka 2004; Kazmin and Tikhonova 2006; Galoyan et al. 2009; Barzegar and Pourkermani 2010; Sudi Ajirlu et al. 2010b). This area, along with other regions of Iran, Turkey, Armenia and the Azerbaijan Republic, were affected by movements of the African (due to Atlantic ocean opening) and Arabian Plate (due to

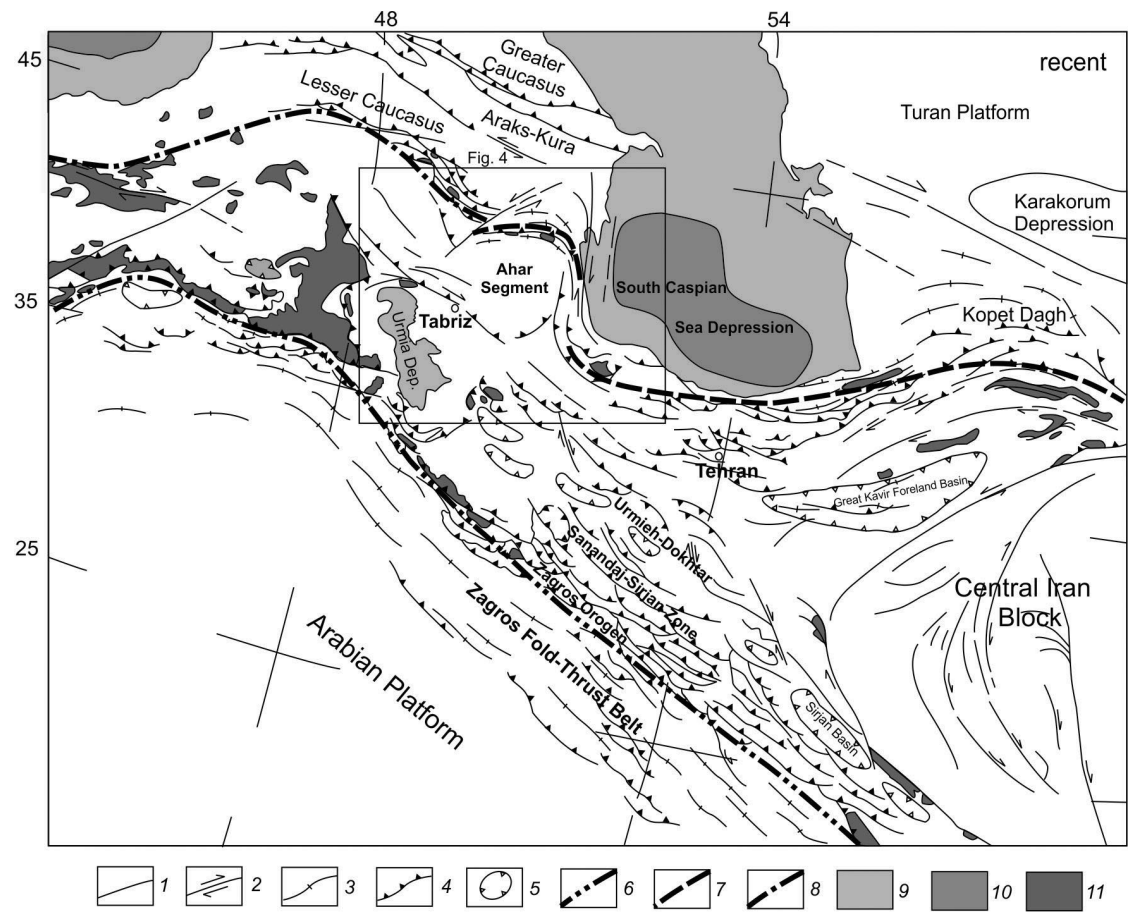

Fig. 2

Main tectonic structures of the Alpine Belt from the Eastern Turkey to Eastern Iran. (1) main fault and structure trend; (2) strike slip fault; (3) anticline; (4) thrust; (5) Cenozoic depression; (6) Zagros-Bitlis suture zone; (7) Allahyarlu-Kaleybar-Northern Iran suture zone; (8) Erzincan-Sevan-Akera suture zone (9) shallow water and lacustrine basin; (10) oceanic lithosphere; (11) paleooceanic remnants. Allahyarlu-KaleybarNorthern Iran suture zone and Erzincan-Sevan-Akera suture zone are distinguished from each other by their ophiolites emplacement ages 
Red Sea opening) (Fig. 2). All these caused compacting, shrinking, folding and faulting in this part of the Earth's crust (Stöcklin 1968; Berberian et al. 1981; Klitgord and Schouten 1986; Zonenshain and Le Pichon 1986; Alavi 1996; Withjack et al. 1998; Allen et al. 2003; Brunet et al. 2003; Nikishin et al. 2003; Bird et al. 2007). The Allahyarlu region in NW Iran is a folded belt. The main fold has an east-west structural trend and constitutes Mt. Samanludagh (Babakhani and Nazer 1991; Barzegar and Pourkermani 2010; Sudi Ajirlu et al. 2010). This fold is an anticlinal one (Barzegar et al. 2010; Sudi Ajirlu et al. 2010b); the Allahyarlu-Hovai reverse fault is oriented along its axial surface. The ophiolitic and metamorphic complexes of Allahyarlu are exposed at the northern edge of the Ahar Block due to movement along this fault.

The main faults of NW Iran are the Tabriz, Talysh, Araks, Myaneh and AllahyarluHovai Faults (Fig. 4).

The Tabriz Fault, with an approximate length of $100 \mathrm{~km}$, stretches from the Mishou Mountains in the west to the city of Bostanabad in the east. This fault divides the Azerbaijan region into two blocks: a northeastern region including the Tabriz and Ardebil areas and the southwestern block of Zanjan (Eftekharnejad 1975). The Tabriz Fault is a dextral strike-slip fault and its formation age is attributed to the Late Devonian (Eftekharnejad 1975; Aghanabati 2004).

The Myaneh Fault of NE-SW trend is a dextral strike-slip fault which is located at the eastern continuation of the Tabriz Fault and stretches along the Garmichai River and south of the Mt. Sabalan (Lescuyer and Riou 1976). One of the reasons for the formation of Mt. Sabalan may be the simultaneous action of the dextral Myaneh Fault to its south and dextral movement of another fault to its north, which caused the formation of a pull-apart basin, where magmas erupted (Lescuyer and Riou 1976).

The Talysh fault is a dextral, reverse and active fault of $\sim 1,400 \mathrm{~km}$ length and an approximately north-south trend (Fig. 3). Based on new studies, two significant faults are found in the Talysh area (Allen et al. 2003, 2005). One of them is a dextral thrust fault

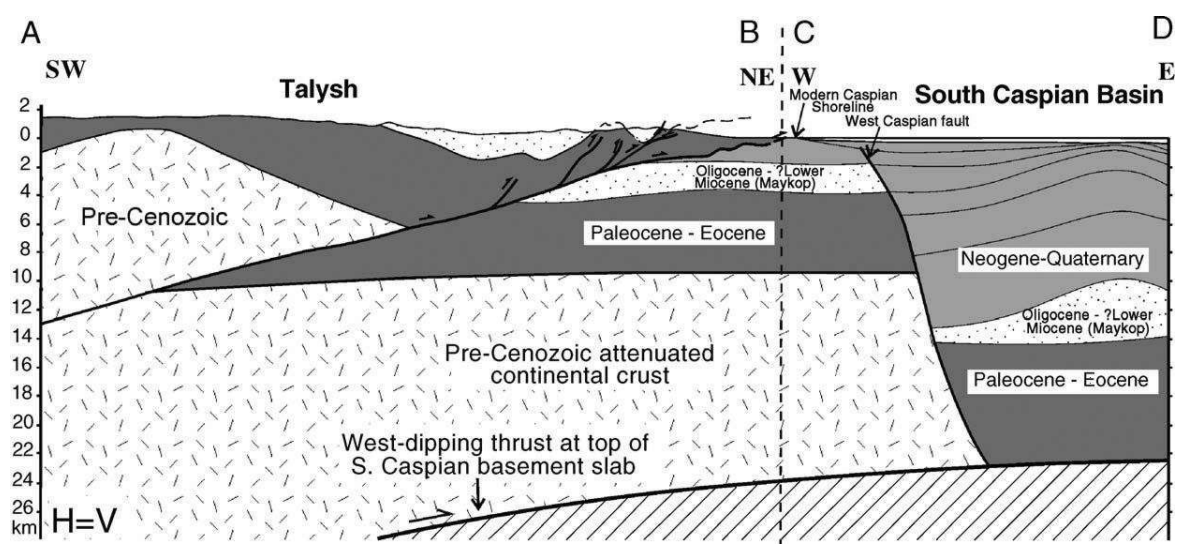

Fig. 3

Cross-section through the eastern Talysh by Allen et al. (2003) 
with a smooth slope toward the SW (Allen et al. 2003); another is a normal fault with an intensive slope toward the east (Allen et al. 2003). Slider and rotational movements occur along the smooth slope of the Talysh Fault (Khalafly 2001; Allen et al. 2005) and West Caspian Sea Basin subsidence occurs along the normal Talysh Fault (Allen et al. 2005).

Some researchers believe that the Talysh Fault is a transform fault and plays a principal role in paleo-ocean evolution in NW Iran and the Lesser Caucasus (Brunet et al. 2003; Golonka 2004; Kazmin and Tikhonova 2006; Adamia et al. 2011). The Talysh Fault formation age is Precambrian (Aghanabati 2004). Dextral movements of this fault displaced Azerbaijan and NW Iran toward higher latitudes (Eftekharnejad 1975; Didon and Gemain 1976; Allen et al. 2005; Kazmin and Tikhonova 2006; Hudson et al. 2008; Sudi Ajirlu and Jahangiri 2010a).

The Araks Fault is one of the most important faults of Azerbaijan and NW Iran; it separates the Lesser Caucasus Block and Transcaucasus Block from the Talysh Plate and the Ahar Block. The Araks Fault is a sinistral strike-slip fault (Alavi 1991b; Barka and Reilinger 1997; Allen et al. 2005; Galoyan et al. 2009; Sosson et al. 2010; Adamia et al. 2011). This fault, of NE-SW trend and with its sinistral movements, displaced NW Iran lithologies (Didon and Gemain 1976; Sudi Ajirlu and Jahangiri 2010a; Adamia et al. 2011).

The Allahyarlu-Hovai Fault of east-west trend (Golonka 2004; Allen et al. 2005; Kazmin and Tikhonova 2006; Barzegar and Pourkermani 2010; Sudi Ajirlu and Jahangiri 2010a) is a sinistral and reverse fault which is located at the Allahyarlu anticlinal core and along the anticline axis (Barzegar and Pourkermani 2010; Sudi Ajirlu et al. 2010b). This reverse fault emplaced older metamorphic rocks next to the ophiolite mélange (Alavi 1991a; Babakhani and Nazer 1991; Barzegar and Pourkermani 2010; Sudi Ajirlu and Jahangiri 2010a).

The Allahyarlu-Kaleybar-Northern Iran Suture Zone, determined by Late Carboniferous to Triassic metamorphic and ophiolitic exposures, was the western continuation of a branch of the Paleotethys Basin in Iran (Alavi 1991b; Ruttner 1993; Alavi 1996; Ghazi et al. 2001; Seyed-Emami 2003; Zanchi et al. 2006; Ghavidel-Syooki 2008; Zanchetta et al. 2009; Omrani and Moazzen 2010; Sheikholeslami and Kouhpeyma 2012; Shafaii Moghadam et al. in press). It is likely that the Allahyarlu ophiolite complex was displaced to higher latitudes by the dextral Talysh Fault (Eftekharnejad 1975; Didon and Gemain 1976; Kazmin and Tikhonova 2006; Zakariadze et al. 2007; Sudi Ajirlu and Jahangiri 2010a).

Concerning the western continuation of the Allahyarlu-Kaleybar Suture Zone, some researchers believe that it may be the Sevan-Akera Suture Zone (Eftekharnejad 1975; Babakhani and Nazer 1991; Zakariadze et al. 2007) but because of dextral Talysh and sinistral Araks Fault activities, the Allahyarlu Suture Zone moved to higher latitudes (Didon and Gemain 1976; Sudi Ajirlu and Jahangiri 2010a). Since the Sevan-Akera Suture Zone is situated at higher latitudes than the Allahyarlu Suture Zone, the probability of its being the western continuation of the Allahyarlu Suture 
Zone is questionable. On the other hand, considering the existence of the Ahar Block, the movements of its confining faults and Khalafly's (2001) research, the Ahar block rotated 6-8 $8^{\circ}$ counterclockwise during the Eocene. Therefore it could be put forward that the western continuation of the Allahyarlu-Kaleybar Suture Zone is the Sevan-Akera Suture Zone. However, it should be mentioned that the opening-closing ages of the Allahyarlu-Kaleybar-Northern Iran ophiolites is Late Carboniferous to Triassic, respectively, while the opening-closing ages of the Sevan-Akera ophiolites is Middle Jurassic to Lower Cretaceous, respectively. Since the Sevan-Akera ophiolites were formed by Neotethys subduction and at its back-arc basin (Galoyan et al. 2009; Rolland et al. 2009; Sosson et al. 2010; Rolland et al. 2011), it is unreasonable to consider the Allahyarlu-Kaleybar Suture Zone as the western continuation of the Sevan-Akera Suture.

\section{The Ahar Block}

(1) Based on the NW Iran tectonic map (Huber et al. 1976; Alavi 1991b; Nogole-Sadat and Almasian 1993), lithological structure features and the main fault trends of the studied region, a block is present that we call the "Ahar Block", which is limited by the Tabriz, Myaneh, Talysh, Allahyarlu-Hovai and Araks Faults (Fig. 4). This block was also called "Ahar Block" by some authors (e.g. Barka and Reilinger 1997) while some others have call it the "Talysh Plate" (e.g. Allen et al. 2003; Golonka 2004; Zanchetta et al. 2009). The Ahar Block underwent rotational and compressional movements caused by confining fault activity (Didon and Gemain 1976; Zonenshain and Le Pichon 1986; Masson et al. 2006; Hudson et al. 2008; Sudi Ajirlu and Jahangiri 2010a). Limited paleomagnetic data from basalts in the Talysh region suggest that $\sim 26^{\circ}$ counterclockwise rotation took place around vertical axes during the Early-Middle Eocene and that 18-20 $0^{\circ}$ clockwise rotation occurred since the Late Eocene (Bazhenov and Burtman 1989; Khalafly 2001; Allen et al. 2005). The main evidence to consider this zone as a block is the existence of mafic and ultramafic rocks and ophiolite mélanges along the Tabriz and Allahyarlu-Hovai Faults (Berberian et al. 1981; Babakhani and Nazer 1991; Sudi Ajirlu and Jahangiri 2010a).

(2) Folding along the Talysh and Allahyarlu-Hovai Faults indicates that northward and northeastward movements and compression are occurring along these faults (Didon and Gemain 1976; Lescuyer and Riou 1976; Zonenshain and Le Pichon 1986; Alavi 1996; Allen et al. 2003, 2005; Masson et al. 2006; Zakariadze et al. 2007; Galoyan et al. 2009)

(3) Bending and conversion of rock units in the Allahyarlu area toward the east and in the Talysh area with a north-south trend indicate that the Talysh Fault underwent dextral movement (Didon and Gemain 1976; Allen et al. 2005; Barzegar and Pourkermani 2010; Sudi Ajirlu and Jahangiri 2010a). 


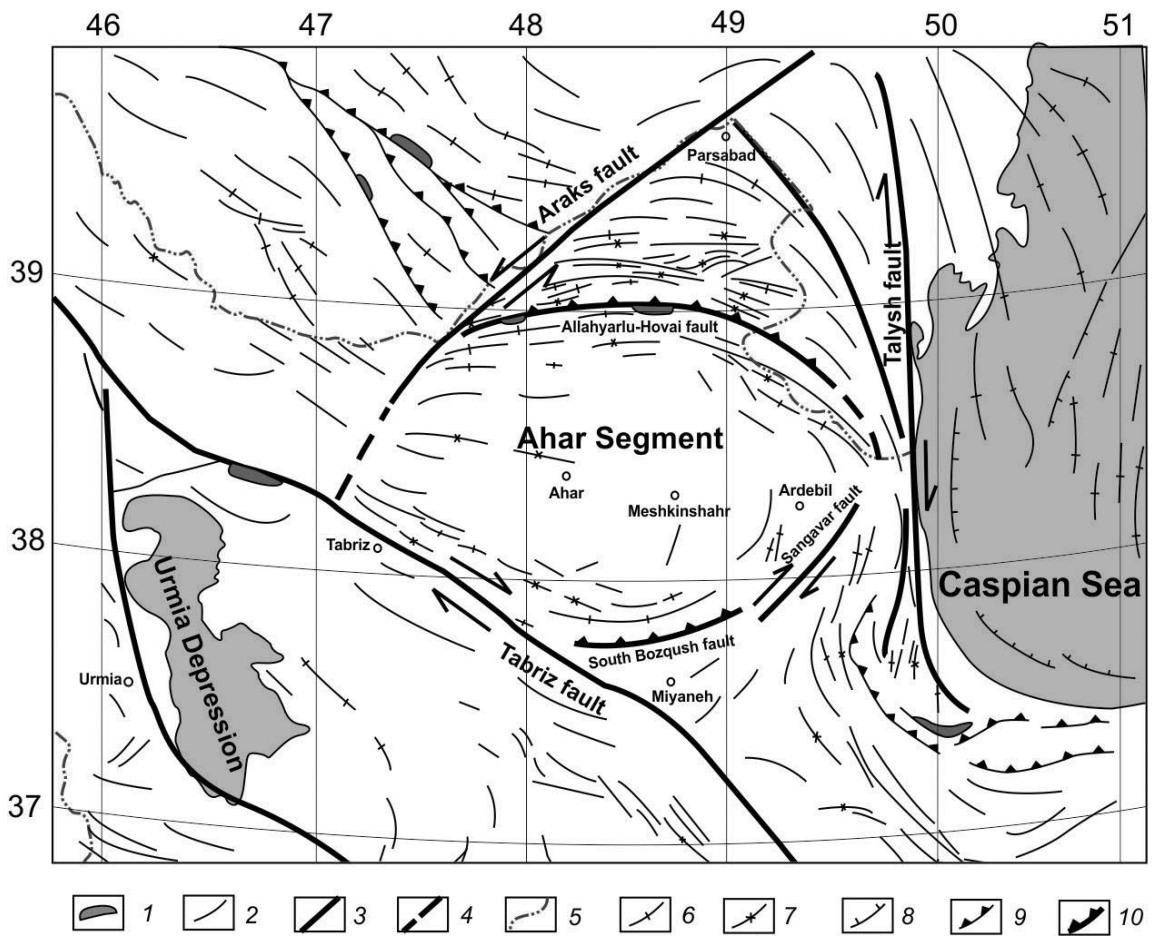

Fig. 4

Ahar block limits. (1) paleooceanic remnants; (2) local structures trend; (3) main fault; (4) concealed fault; (5) country boundaries; (6) anticline; (7) syncline; (8) subsidence area; (9) major thrust; (10) Allahyarlu-Hovai thrust

(4) Bending and conversion of rock units in the Kaleybar area to the west indicate that the Araks Fault underwent sinistral movement (Nogole-Sadat 1994; Barzegar and Pourkermani 2010).

(5) Dextral and thrust movements of the Talysh Fault and sinistral movements of the Araks Fault resulted in northward movements of the Ahar Block (Barzegar and Pourkermani 2010; Sudi Ajirlu and Jahangiri 2010a).

Based on slider movements of the Azerbaijan Block (Didon and Gemain 1976; Lescuyer and Riou 1976; Zonenshain and Le Pichon 1986; Masson et al. 2006) and considering that the Ahar Block is part of the Azerbaijan Block (Brunet et al. 2003; Golonka 2004; Masson et al. 2006), the Allahyarlu ophiolite marking the suture can be considered as the western continuation of the northern Iran ophiolitic and metamorphic belt.

A few lines of evidence can be used to put constraints of timing on rifting in the Allahyarlu-Kaleybar-Northern Iran Basin. Some of this evidence is as follows: the Si- 
lurian limestone with interlayers of spilite is exposed in the south Bandar-e-Anzali area (Stampfli 1978); Late Devonian fossiliferous sediments with basaltic flows are reported from the north Ghazvin area (Annels et al. 1975); Silurian gypsum sediments with Soltan Meydan basalt are present in the South Gonbade Qabus area (Jenny 1977; Stampfli 1978), and are formed within the Niour Formation in the Torud area (Hushmandzadeh 1977); Devonian-Carboniferous gabbro and basalt are found to the west of the city of Gorgan (Jamshidi et al. 1991); Devonian-Carboniferous basaltic flows also formed within the Jeyrood Formation in the Jeyrood Valley (Stöcklin 1972; Majidi 1978; Alavi 1991a); Late Devonian basalt can be found in the Alam Kuh area (Reyre and Mohafez 1972). According to the evidence of the mafic and ultramafic rocks within a limited time interval (mainly Silurian to Carboniferous) mentioned above, rifting in the Allahyarlu-Kaleybar-Northern Iran Basin started in the Silurian and its spreading continued up to Late Devonian (Stampfli 1978; Alavi 1991a; Stampfli et al. 2001; Sheikholeslami and Kouhpeyma 2012).

Taking into account all facts discussed so far, the geologic reconstruction of Eastern Turkey, the Lesser Caucasus and NW Iran from Late Carboniferous to the Recent is described as follows.

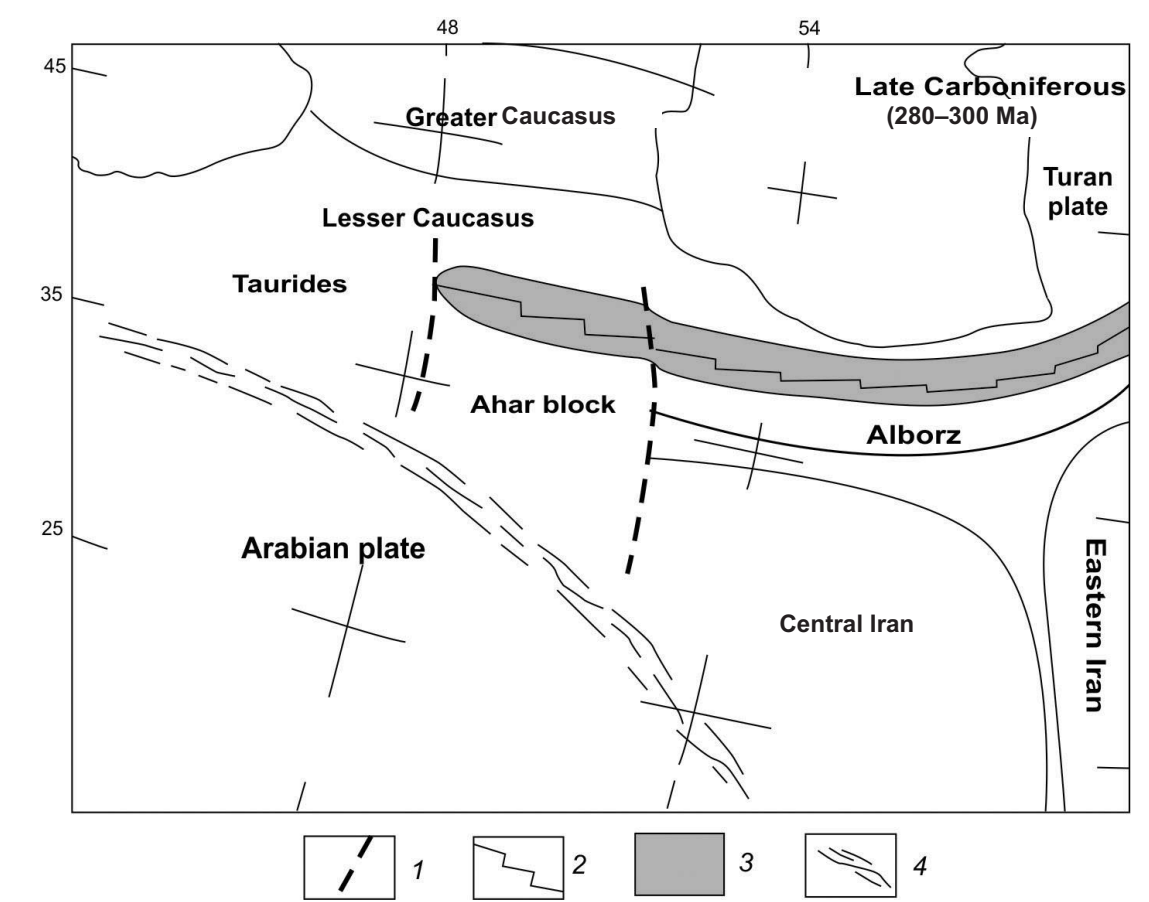

Fig. 5

Paleogeographical reconstruction for 280-300 Ma (Late Carboniferous). (1) transform fault; (2) spreading axis; (3) continental slope and basin with continental crust; (4) basin with oceanic crust. The three transitional faults (from right to left): Talysh fault, Araks fault, NE Anatolian fault 


\section{Late Carboniferous}

The basaltic eruptions and diabasic injections within the Permian and Carboniferous sediments (Devonian-Carboniferous gabbro and basalt to the west of the city of Gorgan, Late Devonian basaltic lava flows in Central Alborz, Devonian-Carboniferous basaltic flows in the Jeyrood Formation in Jajrood Valley, Late Devonian basalt in Alam Kuh, Silurian limestone with spilite interlayers, etc.) indicate that the Allahyarlu-Kaleybar-Northern Iran rift (Fig. 5) existed from the Silurian to the Carboniferous (Alavi 1991a; Jamshidi et al. 1991; Eftekharnejad and Asadian 1992; Sheikholeslami and Kouhpeyma 2012). This basin is divided into four segments by the main Talysh, Araks and NE Anatolian Faults (Glennie 1992; Golonka 2004; Kazmin and Tikhonova 2006). These segments are the Alborz-Central Iran Block, the Ahar Block, the Armenian Block and the Eastern Pontides Block. Each of these four segments underwent a different geologic evolution (Golonka 2004; Kazmin and Tikhonova 2006; Zanchi et al. 2006; Zakariadze et al. 2007; Galoyan et al. 2009; Sosson et al. 2010). The main Neotethys Basin was widening at this time (Glennie 1992; Alavi 1994; Golonka 2004; Shahabpour 2005; Kazmin and Tikhonova 2006; Sheikholeslami et al. 2008; Arfania and Shahriari 2009; Glennie et al. 2011; Kargaranbafghi et al. 2012).

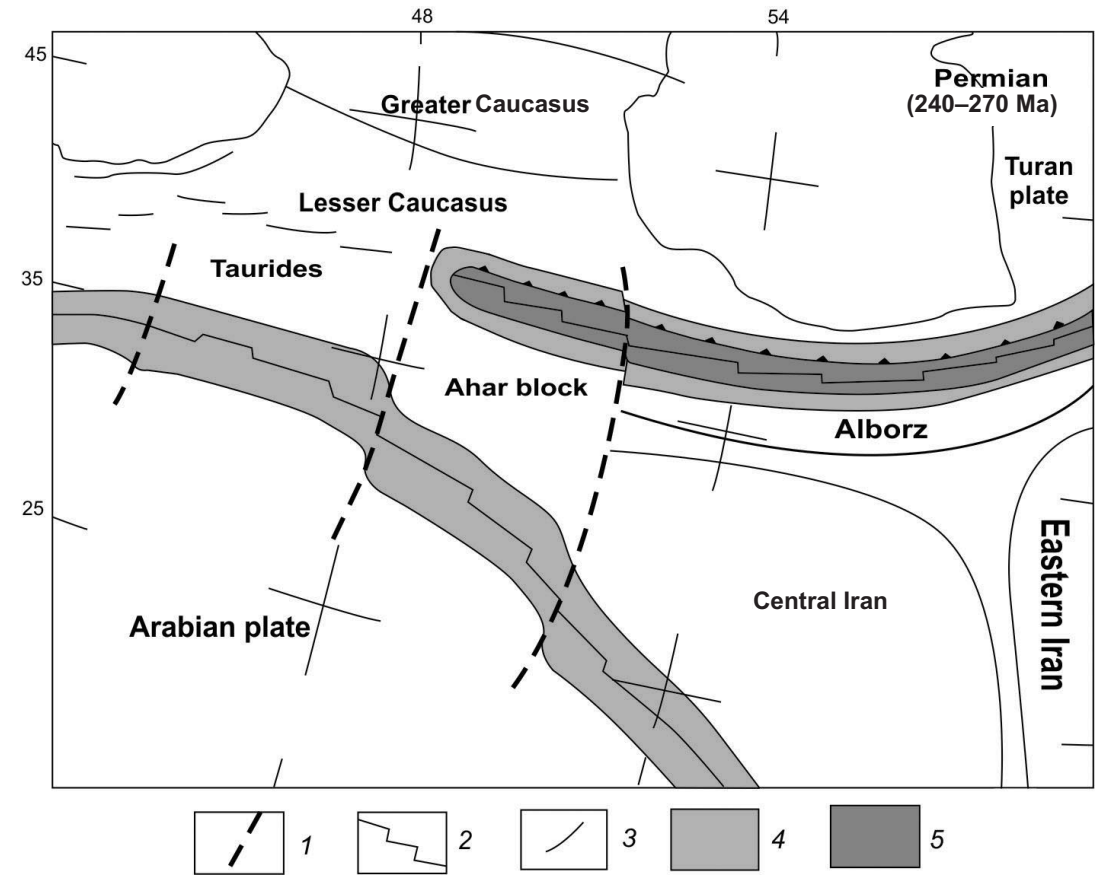

Fig. 6

Paleogeographical reconstruction for 240-270 Ma (Permian). (1) transform fault; (2) spreading axis; (3) local structures trend; (4) continental slope and basin with continental crust; (5) basin with oceanic crust 
Permian

The Allahyarlu-Kaleybar-Northern Iran rift was spreading (Fig. 6) during the Early Permian. Owing to the pressure from the Arabian Block and continuation of Neotethys spreading, the Allahyarlu-Kaleybar-Northern Iran Basin began northward subduction. Therefore the northern margin of this basin changed to an active continental margin (Alavi 1991a; Natalin and Sengör 2005; Sheikholeslami and Kouhpeyma 2012), while the main Neotethys Basin was spreading (Glennie 1992; Alavi 1994; Golonka 2004; Shahabpour 2005; Sheikholeslami et al. 2008; Arfania and Shahriari 2009; Kargaranbafghi et al. 2012).

\section{Late Triassic-Early Jurassic}

The Allahyarlu-Kaleybar-Northern Iran Basin was closed in the Late Triassic (Fig. 7) and only a shallow-water and lacustrine basin remained (Alavi 1991a; Jamshidi et al. 1991; Eftekharnejad and Asadian 1992; Sheikholeslami and Kouhpeyma 2012). Due to Middle to Late Triassic rifting between North America and Africa at this time (Klitgord and Schouten 1986; Withjack et al. 1998; Bird et al. 2007), pressure from the African and Arabian Plates led to the initiation of northeastward subduction of the

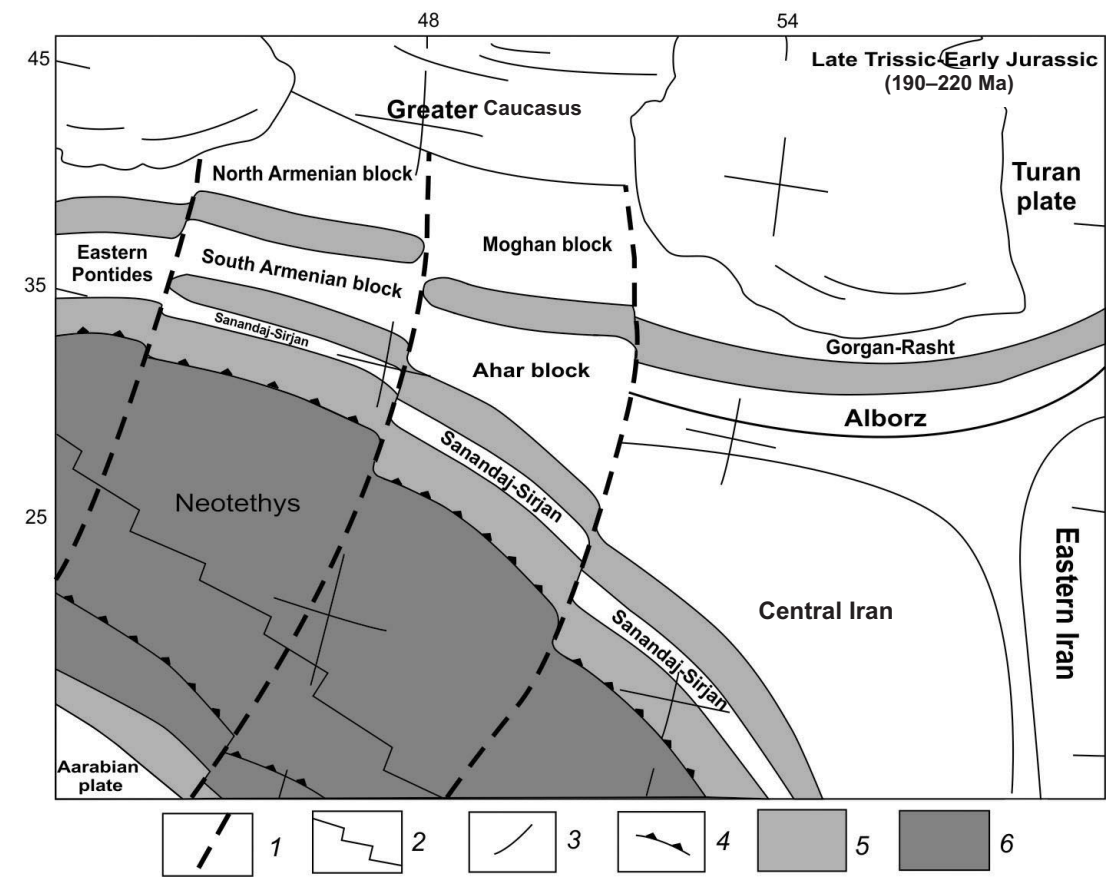

Fig. 7

Paleogeographical reconstruction for 190-220 Ma (Late Triassic-Early Jurassic). (1) transform fault; (2) spreading axis; (3) local structures trend; (4) subduction zone; (5) continental slope and basin with continental crust; (6) basin with oceanic crust 
main Neotethys Basin. This created a shallow-water basin between the North Armenian and the South Armenian Blocks called the Sevan-Akera Basin. This basin began opening 165.3 $\pm 1.7 \mathrm{Ma}$ ago (Galoyan et al. 2009; Rolland et al. 2011). The Armenian Basin, as a Neotethyan back-arc basin, was an active Andean-type margin during the Middle Jurassic-Lower Cretaceous (Brunet et al. 2003; Kazmin and Tikhonova 2006; Galoyan et al. 2009; Rolland et al. 2009; Sosson et al. 2010; Rolland et al. 2011). A tensional basin was formed between the Sanandaj-Sirjan and the Central Iran zones, which later created Neotethys II (Glennie 1992; Alavi 1994; Sengör and Natal'in 1996; Golonka 2004; Shahabpour 2005; Sheikholeslami et al. 2008; Arfania and Shahriari 2009; Glennie et al. 2011; Kargaranbafghi et al. 2012). Glennie (1992) called the main Neotethys basin Neotethys 1 and the basin between the Sanandaj-Sirjan and the Central Iran zones Neotethys 2.

Late Jurassic

The Allahyalu-Kaleybar-Northern Iran Basin completely closed in the Late Jurassic (Fig. 8) and its remnants were covered by Shemshak Formation sediments (Sengör 1984; Glennie 1992; Golonka 2004; Kazmin and Tikhonova 2006; Wilmsen et al.

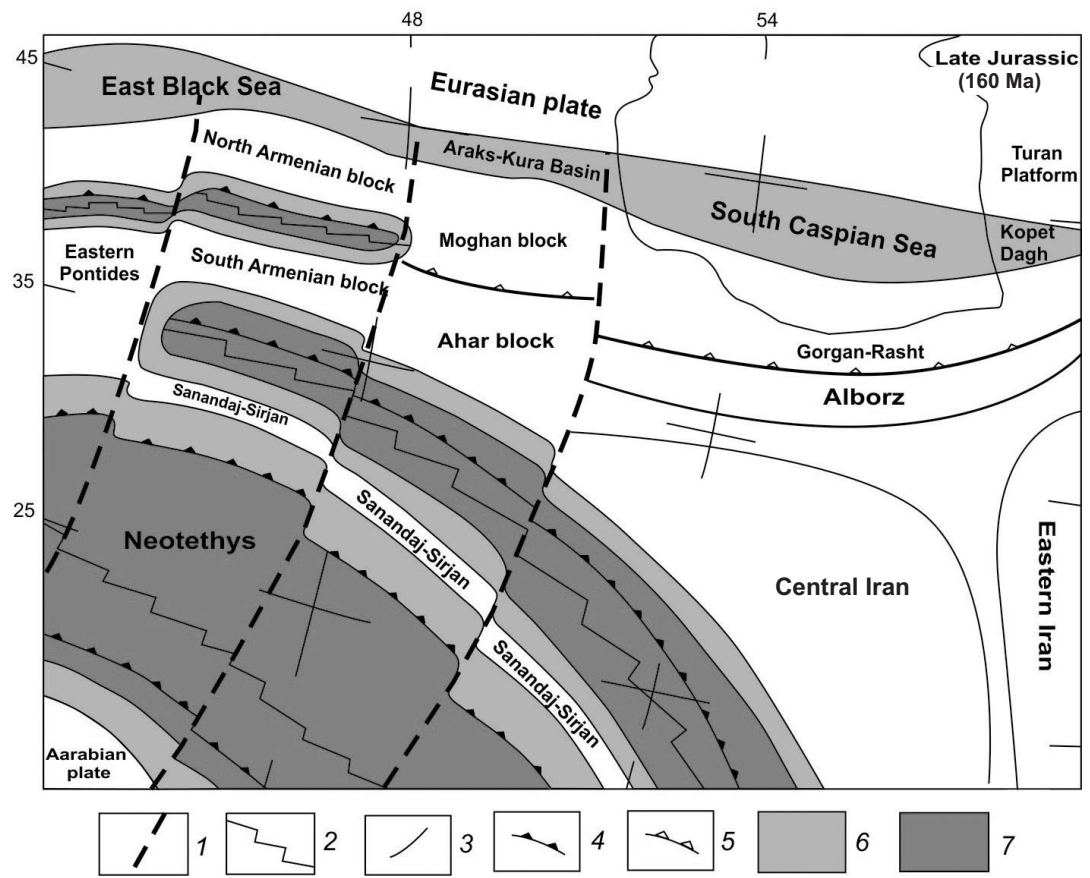

Fig. 8

Paleogeographical reconstruction for $160 \mathrm{Ma}$ (Late Jurassic). (1) transform fault; (2) spreading axis; (3) local structures trend; (4) subduction zone; (5) continental collision situation; (6) shallow-water basin, continental slope and basin with continental crust; (7) basin with oceanic crust 
2009; Sheikholeslami and Kouhpeyma 2012). The Sevan-Akera Basin, which began northward subduction beneath the North Armenian Block from the early Upper Jurassic, was narrowing at this time (Brunet et al. 2003; Kazmin and Tikhonova 2006; Galoyan et al. 2009; Rolland et al. 2009; Sosson et al. 2010; Rolland et al. 2011). The rifting and opening of the South Caspian-Black Sea Basin, which opened in the Middle Jurassic, continued in the Late Jurassic (Berberian 1983; Bazhenov et al. 1996; Brunet et al. 2003; Nikishin et al. 2003; Hinds et al. 2004; Kazmin and Tikhonova 2006). The Neotethys 2 basin became wider; the Neotethys 1 basin subduction continued, making it narrower (Glennie 1992; Alavi 1994; Sengör and Natal'in 1996; Golonka 2004; Shahabpour 2005; Sheikholeslami et al. 2008; Arfania and Shahriari 2009; Glennie et al. 2011; Kargaranbafghi et al. 2012).

\section{Early Cretaceous}

The South Caspian-Black Sea Basin continued spreading at this time (Fig. 9). Subduction in the Sevan-Akera Basin also continued (Brunet et al. 2003; Kazmin and Tikhonova 2006; Galoyan et al. 2009; Rolland et al. 2009, 2011). Spreading of Neotethys 2 continued and because of Atlantic Basin spreading and Arabian Plate

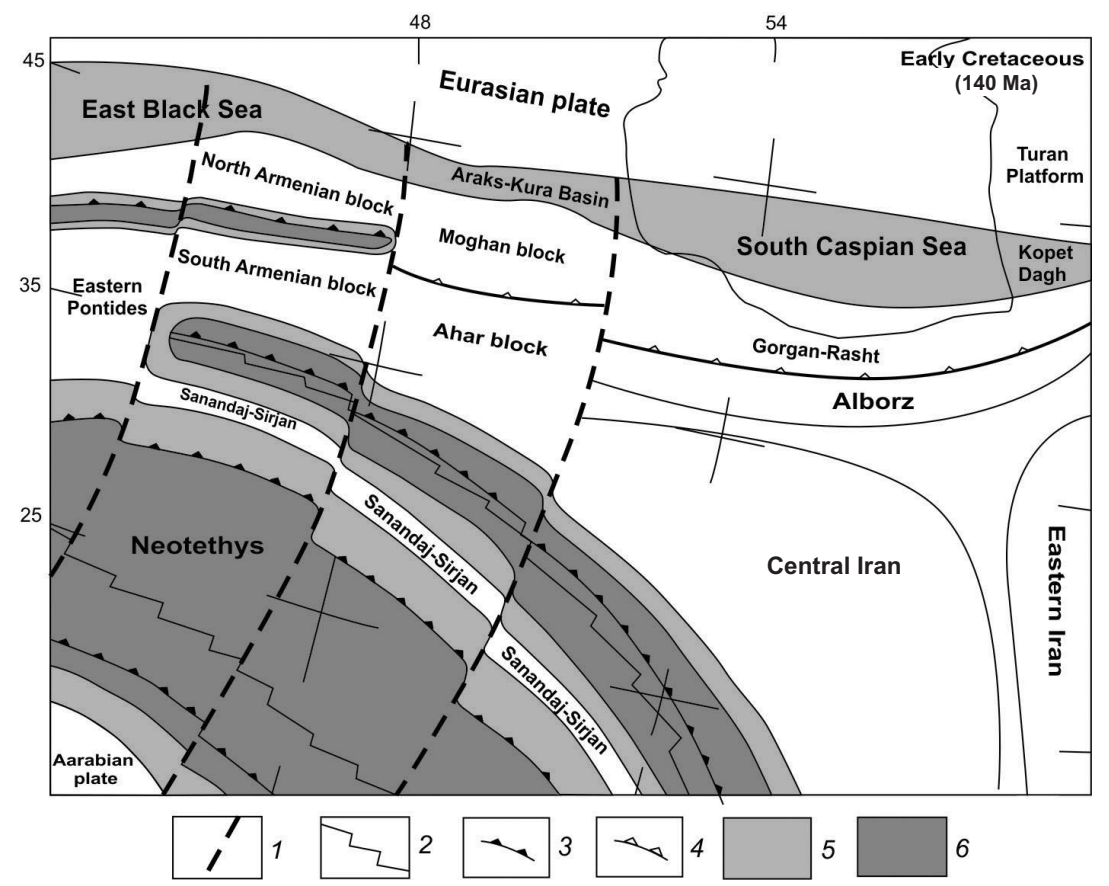

Fig. 9

Paleogeographical reconstruction for $140 \mathrm{Ma}$ (Early Cretaceous). (1) transform fault; (2) spreading axis; (3) subduction zone; (4) continental collision place; (5) shallow-water basin, continental slope and basin with continental crust; (6) basin with oceanic crust 
pressure, Neotethys 1 subduction continued (Glennie 1992; Alavi 1994; Sengör and Natal'in 1996; Golonka 2004; Shahabpour 2005; Arfania and Shahriari 2009; Kargaranbafghi et al. 2012).

Albian

Widespread rifting in central and eastern Iran (Fig. 10) occurred in the Albian (Camp and Griffis 1982; Tirrul et al. 1983; Golonka 2004; Kazmin and Tikhonova 2006). This rifting caused the opening of shallow-water basins between the Central Iran, the Alborz and the Eastern Iran-Afghan Blocks (Camp and Griffis 1982; Tirrul et al. 1983; Zarrinkoub et al. 2010; 2012). The Sevan-Akera Basin closed and only a continental and shallow-water basin remained (Brunet et al. 2003; Kazmin and Tikhonova 2006; Galoyan et al. 2009; Rolland et al. 2009, 2011). Subduction of the Neotethys 1 oceanic crust continued and spreading of Neotethys 2 continued (Glennie 1992; Alavi 1994; Sengör and Natal'in 1996; Golonka 2004; Shahabpour 2005; Sheikholeslami et al. 2008; Arfania and Shahriari 2009; Kargaranbafghi et al. 2012).

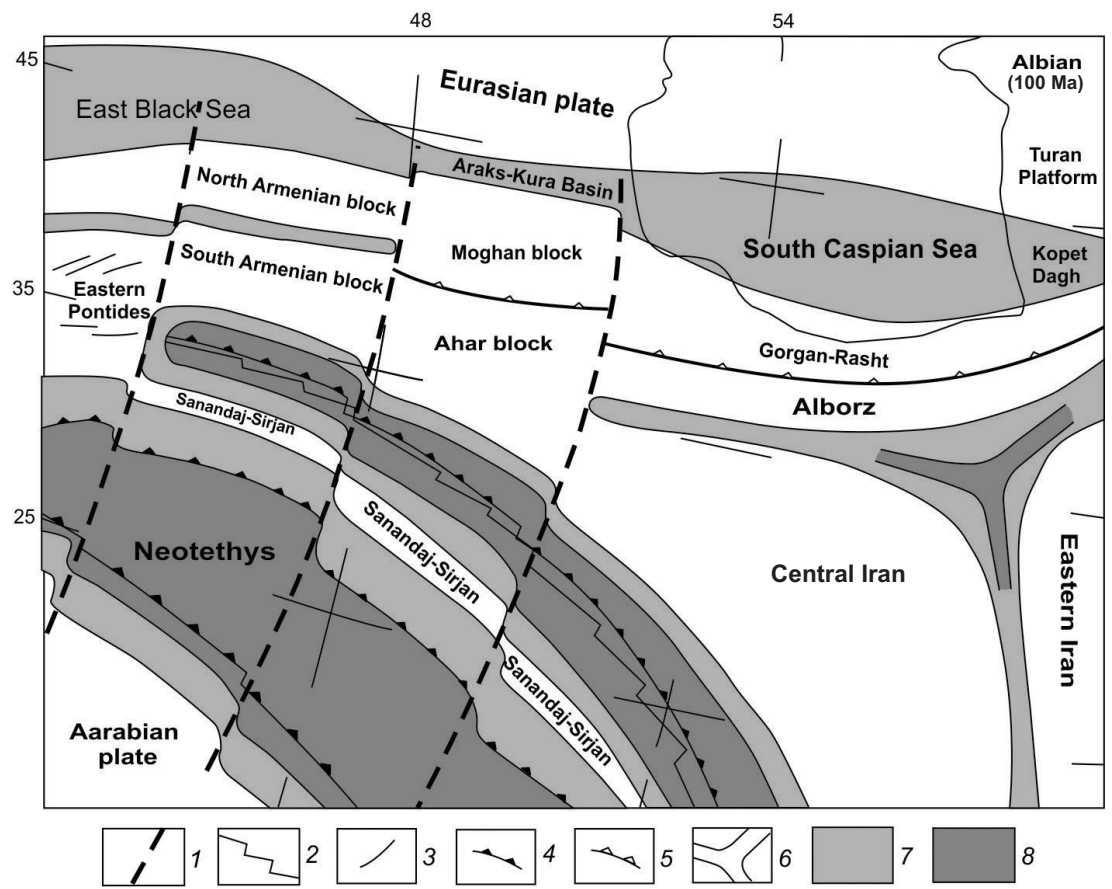

Fig. 10

Paleogeographical reconstruction for $100 \mathrm{Ma}$ (Albian). (1) transform fault; (2) spreading axis; (3) local structures trend; (4) subduction zone; (5) continental collision place; (6) Inner Iran triple junction; (7) shallow-water basin, continental slope and basin with continental crust; (8) basin with oceanic crust 


\section{Late Upper Cretaceous}

Because of pressure from the Arabian Plate, the Central and Eastern Iran Basins formed during Early Cretaceous to Maastrichtian and were spreading, changing to an active environment (Fig. 11; Camp and Griffis 1982; Tirrul et al. 1983; Zarrinkoub et al. 2010, 2012). Therefore the tectonic regime between the Central Iran Plate and the Sanandaj-Sirjan Plate (Neotethys 2) changed from a passive to an active convergent environment. Ophiolites between the Arabian and the Sanandaj-Sirjan Plates (Neotethys 1) were emplaced and only a shallow-water basin remained of Neotethys 1 (Glennie 1992; Alavi 1994; Sengör and Natal'in 1996; Ghebreab 1998; Golonka 2004; Shahabpour 2005; Sheikholeslami et al. 2008; Arfania and Shahriari 2009; Kargaranbafghi et al. 2012).

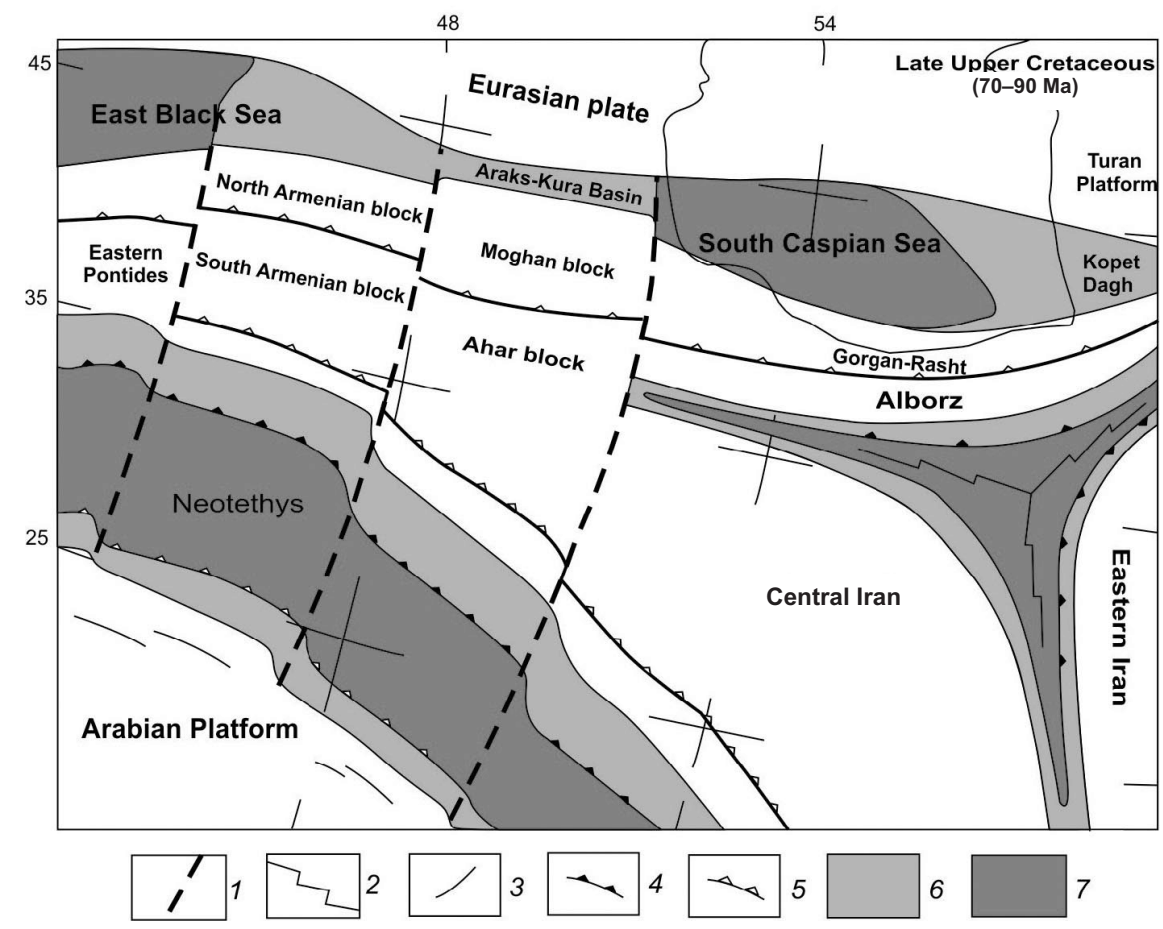

Fig. 11

Paleogeographical reconstruction for 70-90 Ma (Late Upper Cretaceous). (1) transform fault; (2) spreading axis; (3) local structures trend; (4) subduction zone; (5) continental collision place; (6) shallow-water basin, continental slope and basin with continental crust; (7) basin with oceanic crust 


\section{Paleocene}

Neotethys 2 became more narrow in the Paleocene and Neotethys 1 was completely closed (Ghebreab 1998; Stern and Johnson 2010; Johnson et al. 2011). The Azerbaijan Block (Didon and Gemain 1976) moved north-northeastward, forming the Kurdamir Uplift (Fig. 12). It led to the separation of the Black Sea from the Caspian Sea (Inan et al. 1997; Kopp and Shcherba 1998; Nikishin et al. 2003; Kazmin and Tikhonova 2006). The Greater Caucasus basin rift was formed at this time (Adamia et al. 1990; Benyamovsky and Shcherba 1999; Nikishin et al. 2003; Stampfli and Hochard 2009; Rolland et al. 2011). The ongoing closure of the inner basins in Central Iran which were formed during the Maastrichtian is reflected in widespread flysch-type deposits and calc-alkaline volcanic eruptions (Dercourt et al. 1986). The basin between Alborz and Central Iran was narrower (Dercourt et al. 1986; Kazmin and Tikhonova 2006) and the Sevan-Akera Basin was completely closed (Brunet et al. 2003; Kazmin and Tikhonova 2006; Galoyan et al. 2009; Sosson et al. 2010; Rolland et al. 2011).

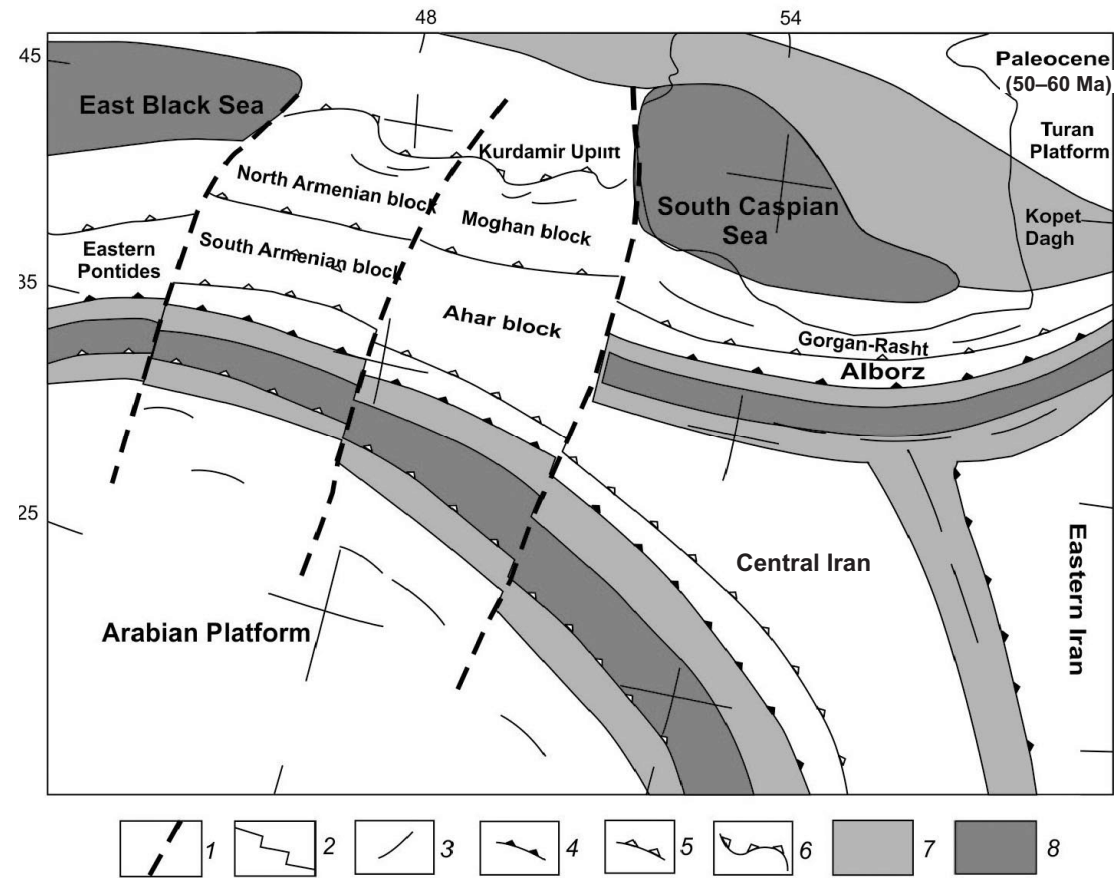

Fig. 12

Paleogeographical reconstruction for 50-60 Ma (Paleocene). (1) transform fault; (2) spreading axis; (3) local structures trend; (4) subduction zone; (5) continental collision place; (6) uplift; (7) shallow-water basin, continental slope and basin with continental crust; (8) basin with oceanic crust 
Oligocene-Miocene

The Red Sea opening at 25 Ma (Ghebreab 1998; Johnson et al. 2011) affected the Ahar and other blocks of NW Iran and led to northward displacements. These movements made the highlands more elevated. Neotethys 2 and the inner basins of Iran were closed (Fig. 13) and only lacustrine environments remained (Glennie 1992; Alavi 1994; Golonka 2004; Shahabpour 2005; Sheikholeslami et al. 2008; Arfania and Shahriari 2009; Glennie et al. 2011; Kargaranbafghi et al. 2012).

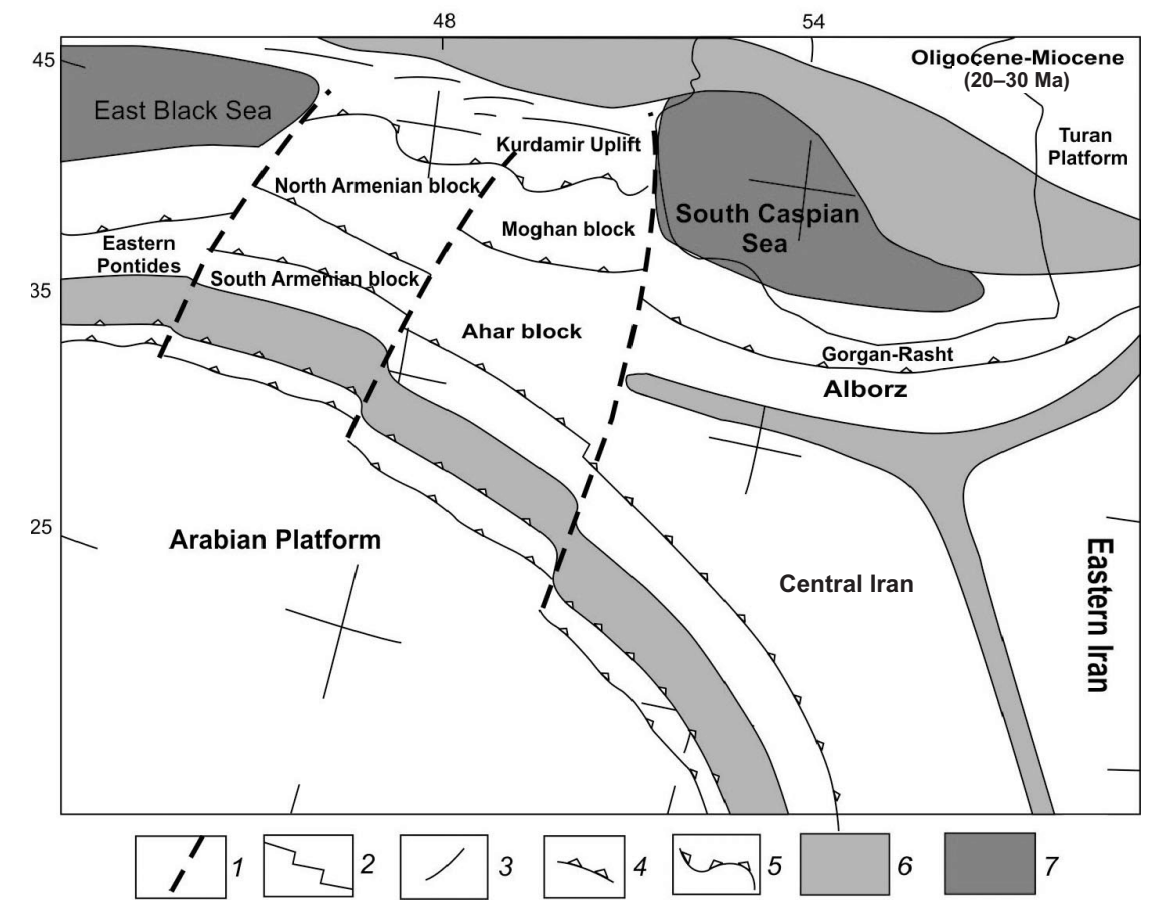

Fig. 13

Paleogeographical reconstruction for 20-30 Ma (Oligocene-Miocene). (1) transform fault; (2) spreading axis; (3) local structures trend; (4) continental collision place; (5) uplift; (6) shallow-water basin, continental slope and basin with continental crust; (7) basin with oceanic crust

\section{Conclusions}

One of the significant oceanic lithosphere remnants in NW Iran is the Allahyarlu ophiolite which is located along the northern border of the Ahar Block. The Allahyarlu-Kaleybar-Northern Iran Suture Zone is one of the most important suture zones in NW Iran-Azerbaijan, indicating the former site of oceanic crust in this area. This suture zone is divided into three parts by the Talysh and Araks Faults, which are the Northern Iran, Allahyarlu-Kaleybar and probably Sevan-Akera Suture Zones. 
Therefore the northern Iran-Allahyarlu-Kaleybar Suture Zone, based on its age span (from Late Carboniferous to Triassic) and its situation, probably marks a branch of the Paleotethys Basin. This Paleotethys branch stretched from the Mashhad ophiolites in NE Iran, the Masuleh and Shanderman ophiolites and metamorphic rocks in North Iran through the Allahyarlu-Kaleybar ophiolites and metamorphic rocks in NW Iran. The Allahyarlu-Kaleybar Suture Zone was moved to higher latitudes, in comparison with other Paleotethys remnants in Iran, by movements of the Araks and Talysh Faults.

\section{Acknowledgements}

We would like to thank the reviewers for their critical comments that improved this paper.

\section{References}

Adamia, Sh., M. Lordkipanidze, I. Kvantaliani, Z. Kutelia 1990: Geology of the Caucasus: A guide of field meeting of the Working group 5.1. Paleogeography and tectonics of the Paleozoic fold areas and their platform frame. Geotraverse 10 (Caucasus), Tbilisi, September 1-6, 1990. - Al. Djanelidze Geological Institute of the Academy of Sciences of USSR, p. 39.

Adamia, Sh.A., M.B. Lordkipanidze, M.A. Beridze 2011: Paleogeography of the Ukrainian Carpathians, the Cimea, and the Caucasus. - In: Rakús et al. (Eds): Evolution of the Northern Margin of Tethys. (Mém. Soc. Géol. Fr., Paris, 1990) Nouvelle Série, Vol. III, Part 1, No. 154, pp. 123-146.

Aghanabati, A. 2004: Geology of Iran. - Geological Survey of Iran, 586 pp. (In Persian).

Alavi, M. 1991a: Sedimentary and structural characteristics of the Paleo-Tethys remnants in northeastern Iran. - Geological Society of American Bulletin, 103, pp. 983-992.

Alavi, M. 1991b: Tectonic Map of Middle East in scale 1:5000000. - Geological Survey of Iran, Tehran.

Alavi, M. 1994: Tectonic of the Zagros orogenic belt of Iran: New data and interpretations. Tectonophysics, 229, pp. 211-238.

Alavi, M. 1996: Tectonostratigraphic synthesis and structural style of the Alborz Mountain System in Iran. - Journal of Geodynamics, 21(1), pp. 1-33.

Allen, M.B., S.J. Vincent, G.I. Alsop, A. Ismail-Zadeh, R. Flecker 2003: Late Cenozoic deformation in the South Caspian region: Effects of a rigid basement block within a collision zone. Tectonophysics, 366, pp. 223-239.

Allen, M.B., A.D. Ismail-Zadeh, R. Flecker, K.A. Foland, M.D. Simmons 2005: Insights from the Talysh of Azerbaijan into the Paleogene evolution of the South Caspian region. - GSA Bulletin, 117(11-12), pp. 1513-1533.

Annels, R.N., R.S. Arthurton, R.A. Bazley, R.G. Davies 1975: Explanatory text of the Qazvin and Rasht quadrangles map. - Geological Survey of Iran, E3 and E4, 94 pp.

Arfania, R., S. Shahriari 2009: Role of southeastern Sanandaj-Sirjan Zone in the tectonic evolution of Zagros Orogenic Belt, Iran. - Island Arc, 18, pp. 555-576.

Babakhani, A., N.H.K. Nazer 1991: 1:100000 Geological Map of Lahrud. - Geological Survey of Iran.

Barka, A., R. Reilinger 1997: Active tectonics of the Eastern Mediterranean region: Deduced from GPS, neotectonic and seismicity data. - Annali di Geofisica, 40(3), $24 \mathrm{pp}$.

Barzegar, A., M. Pourkermani 2010: Structural evolution of folded zone of Allahyarlu in western Alborz. $-21^{\text {st }}$ Congress of Geological Sciences and $15^{\text {th }}$ Congress of Geological Survey of Iran, Urmia University (In Persian).

Bazhenov, M.L., V.S. Burtman 1989: Palaeomagnetism of Upper Cretaceous rocks from the Caucasus and its implications for tectonics. - In: Sengör, A.M.C. (Ed.), Tectonic Evolution of the Tethyan Region. Dordrecht, Kluwer Academic Publishers, pp. 217-239. 
Bazhenov, M.L., V.S. Burtman, N.L. Levashova 1996: Lower and middle Jurassic paleomagnetic results from the south Lesser Caucasus and the evolution of the Mesozoic Tethys ocean. - Earth and Planetary Science Letters, 14, pp. 79-89.

Benyamovsky, V.N., I.G. Shcherba 1999: Paleobathymetry and anoxic environments in the Late Paleocene Basin of the Greater Caucasus in the light of new micropaleontological data. - Earth Science, 369A(9), pp. 1264-1267.

Berberian, M. 1983: The southern Caspian: A compressional depression floored by a trapped, modified oceanic crust. - Canadian Journal of Earth Sciences, 20, pp. 163-183.

Berberian, M., A. Babakhani, S.M. Amidi 1981: Discovery of southern continuation of Sevan-Akera ophiolitic belt in northwestern Iran. - Internal report of the Geological Survey, 12 pp. (In Persian).

Bird, D.E., S.A. Hall, K. Burke, J.F. Casey, D.S. Sawyer 2007: Early Central Atlantic Ocean sea floor spreading history. - Geosphere, 3(5), pp. 282-298.

Brunet, M.F., M.V. Korotaev, A.V. Ershov, A.M. Nikishin 2003: The South Caspian Basin: A review of its evolution from subsidence modeling. - Sedimentary Geology, 156, pp. 119-148.

Camp, V.E., R.J. Griffis 1982: Character, genesis and tectonic setting of igneous rocks in the Sistan suture zone, eastern Iran. - Lithos, 3, pp. 221-239.

Dercourt, J., L.P. Zonenshain, L.E. Ricou, V.G. Kazmin, X. Le Pichon, A.L. Knipper, C. Grandjacquet, I.M. Sbortshikov, V. Geyssant, C. Lapurier, D.H. Perhersky, J. Boulin, J.C. Sibuet, L.A. Savostin, O. Sorokhtin, M. Westphal, M.X. Bazhenov, J.P. Lauer, B. Biju-Duval 1986: Geological evolution of the Tethys belt from the Atlantic to the Pamirs since the Lias. - Tectonophysics, 123, pp. 241-315.

Didon, J., Y.A. Gemain 1976: Le Sabalan volcan Plio-Quareanaire de 1 Azerbaijan oriental (Iran): Etude the geologique du l'edifice et de son environment regional. These 3 emcycle. - Univ. Scientifique et Medicale de Grenoble, France.

Eftekharnejad, J. 1975: Brief history and structural development of Azerbaijan. - Geological Survey of Iran, Internal Report (In Persian).

Eftekharnejad, J., A. Asadian 1992: Age of metamorphic and ophiolitic complex of Asalem-Shanderman and its geodynamic relation with Paleotethys and Caspian oceanoide lithosphere. - Journal of Earth Sciences, Geological Survey of Iran, No. 3 (In Persian).

Galoyan, G., Y. Rolland, M. Sosson, M. Corsini, S. Billo, C. Verati, R. Melkonyan 2009: Geology, geochemistry and 40Ar/39Ar dating of Sevan Ophiolite (Lesser Caucasus, Armenia): Evidences for Jurassic Back-arc opening and hot spot event between the South Armenian Block and Eurasia. Journal of Asian Earth Sciences, 34, pp. 135-153.

Ghavidel-Syooki, M. 2008: Palynostratigraphy and palaeogeography of the Upper Ordovician Gorgan Schists (Southeastern Caspian Sea), Eastern Alborz Mountain Ranges, Northern Iran. Comunicações Geológicas, 95, pp. 123-155.

Ghazi, M., A.A. Hassanipak, P.J. Tucker, K. Mobasher 2001: Geochemistry and 40Ar-39Ar ages of the Mashhad Ophiolite, NE Iran. - Abstract in Bos. Trans. AGU, S2(47), Fall Meet.

Ghebreab, W. 1998: Tectonics of the Red Sea region reassessed. - Earth-Science Reviews, 45, pp. 1-44.

Glennie, K.W. 1992: Plate tectonics and the Oman mountains. Tribulus, 2(2), pp. 11-21.

Glennie, K.W., S.G. Fryberger, C. Hern, L. Lancaster, J.T. Teller, V.P. Pandey, A.K. Singhvi 2011: Geological importance of luminescence dates in Oman and the Emirates: An overview. - Geochronometria, 38(3), pp. 259-271.

Golonka, J. 2004: Plate tectonic evolution of the southern margin of Eurasia in the Mesozoic and Cenozoic. - Tectonophysics, 381, pp. 235-273.

Hinds, D.J., E. Aliyeva, M.B. Allen, C.E. Davies, S.B. Kroonenberg, M.D. Simmons, S.J. Vincent 2004: Sedimentation in a discharge dominated fluvial-lacustrine system: The Neogene Productive Series of the South Caspian Basin, Azerbaijan. - Marine and Petroleum Geology, 21, pp. 613-638.

Huber, H., A. Afghani, M.M. Salek, J. Moazami 1976: Tectonic map of Northwest Iran in scale 1:2500000. - National Iranian Oil Company Exploration and Production, Tehran.

Hudson, S.M., C.L. Johnson, M.A. Efendiyeva, H.D. Rowe, A.A. Feyzullayev, C.S. Aliyev 2008: Stratigraphy and geochemical characterization of the Oligocene-Miocene Maikop series: Implications for the paleogeography of Eastern Azerbaijan. - Tectonophysics, 451, pp. 40-55. 
Hushmandzadeh, H. 1977: The evolution of geological phenomena in Torud. - Internal report of Geological Survey of Iran (In Persian).

Inan, S., M.N. Yalcin, I.S. Guliev, K. Kuliev, A.A. Feizullayev 1997: Deep petroleum occurrences in the Lower Kura depression, South Caspian Basin, Azerbaijan: An organic chemical and basin modelling study. - Mar. Pet. Geol., 14, pp. 731-762.

Jamshidi, Kh., A. Afsharanzadeh, M. Sahbani, M. Manouchehri 1991: 1:250000 Scale Geological Map of Gorgan. - Geological Survey of Iran.

Jenny, J. 1977: Precambrian et Paleozoique inferieur de l'Elburz oriental entre Aliabad et Shahrud, Iran NE. - Eclog. Geol. Helv., 70(3), pp. 761-770.

Johnson, P.R., A. Andresen, A.S. Collins, A.R. Fowler, H. Fritz, W. Ghebreab, T. Kusky, R.J. Stern 2011: Late Cryogenian-Ediacaran history of the Arabian-Nubian Shield: A review of depositional, plutonic, structural, and tectonic events in the closing stages of the northern East African Orogen. Journal of African Earth Sciences, 61, pp. 167-232.

Kargaranbafghi, F., F. Neubauer, G. Genser, A. Faghih, T. Kusky 2012: Mesozoic to Eocene ductile deformation of western Central Iran: From Cimmerian collisional orogeny to Eocene exhumation. Tectonophysics, 564-565, pp. 83-100.

Kazmin, V.G., N.F. Tikhonova 2006: Late Cretaceous-Eocene marginal seas in the Black Sea-Caspian region: Paleotectonic reconstructions. - Geotectonics, 40(3), pp. 169-182.

Khalafly, A.A. 2001: Paleomagnetism and critical paleolatitudes of the Paleogene depressions in the Lesser Caucasus. - Proceedings of the National Academy of Sciences, Earth Sciences, 1, pp. $110-113$ (in Russian).

Klitgord, K.D., H. Schouten 1986: Plate kinematics of the central Atlantic. In: Vogt, P.R., B.E. Tucholke (Eds), The Geology of North America: The Western North Atlantic Region: Boulder, Colorado. Geological Society of America, v. M, pp. 351-378.

Kopp, M.L., I.G. Shcherba 1998: Caucasian Basin in the Paleogene. - Geotectonics, 32(2), pp. 93-113.

Lescuyer, J.L., R. Riou 1976: Geologic de la region de Myaneh (Azerbaijan), Contribution an l'etude du volcanism tertiary de Iran. These de 3ème cycle. - Grenoble, 233 pp.

Majidi, B. 1978: Etude pérostructurale de la région de Mashhad (Iran). Les problèmes des métamorphites, serpentinites et granitoides hercyniens. Thèse de Docteur Ingenieur. - Université Scientifique et Médicale de Grenoble, $277 \mathrm{pp}$.

Majidi, B. 1981: The ultrabasic lava flows of Mashhad, North East Iran. - Geological Magazine, 118(1), pp. 49-58.

Masson, F., Y. Djamour, S. Van Grop, J. Chery, M. Tatar, F. Tvakoli, H. Nankali, P. Vernant 2006: Extension in NW Iran driven by the motion of the South Caspian Basin. - Earth and Planetary Science Letters, 252, pp. 180-188.

Natalin, B.A., A.M.C. Sengör 2005: Late Palaeozoic to Triassic evolution of the Turan and Scythian platforms: The pre-history of the Palaeo-Tethyan closure. - Tectonophysics, 404, pp. 175-202.

Nikishin, A.M., M.V. Korotaev, A.V. Ershov, M.F. Brunet 2003: The Black Sea basin: Tectonic history and Neogene - Quaternary rapid subsidence modeling. - Sedimentary Geology, 156, pp. 149-168.

Nogole-Sadat, M.A.A., M. Almasian 1993: Tectonic Map of Iran in scale 1:1,000,000. - Geological Survey of Iran, Tehran.

Nogole-Sadat, M.A.A. 1994: Main structural elements of NW Iran (Azerbaijan). - First Geology and Mine Congress of NW Iran, Tabriz University (In Persian).

Omrani, H., M. Moazzen 2010: Amphibole, chlorite and zoisite, retrograde metamorphism phases in Shanderman eclogite. - Journal of Crystallography and Mineralogy of Iran, 18(3), 12 pp. (In Persian).

Reyre, D., S. Mohafez 1972: A first contribution of the NIOC-ERAP agreement to the Knowledge of Iranian Geology. - Edition Technips, Paris, 58 pp.

Rolland, Y., Gh. Galoyan, D. Bosch, M. Sosson, M. Corsini, M. Fornari, C. Verati 2009: Jurassic back-arc and Cretaceous hot-spot series in the Armenian ophiolites - Implications for the obduction process. - Lithos, 112, pp. 163-187. 
Rolland, Y., M. Sosson, Sh. Adamia, N. Sadradze 2011: Prolonged Variscan to Alpine history of an active Eurasian margin (Georgia, Armenia) revealed by 40Ar/39Ar dating. - Gondwana Research, 20, pp. 798-815.

Ruttner, A.W. 1993: Southern borderland of Triassic Laurasia in north-east Iran. - Geologische Rundschau, 82, pp. 110-120.

Sengör, A.M.C. 1984: The Cimmeride orogenic system and the tectonics of Eurasia. - Geological Society of America Special Publication 195.

Sengör, A.M.C. 1990: Plate tectonics and orogenic research after 25 years: A Tethyan perspective. Earth-Science Reviews, 27, pp. 1-201.

Sengör, A.M.C., B.A. Natal'in 1996: Palaeotectonics of Asia: fragments of a synthesis. - In: Yin, A., M. Harrison (Eds), The Tectonic Evolution of Asia, Rubey Colloquium. Cambridge University Press, Cambridge, pp. 486-640.

Seyed-Emami, K. 2003: Triassic in Iran. - Facies, 48, pp. 91-106.

Shafaii Moghadam, H., X. Li, X. Ling, R. Stern, M.Z. Khedr, M. Chiardia, G. Chorbani, S. Arai, A. Tamura (in press): Devonian to Permian evolution of the Paleo-Tethys Ocean: New evidence from $\mathrm{U}-\mathrm{Pb}$ zircon dating and $\mathrm{Sr}-\mathrm{Nd}-\mathrm{Pb}$ isotopes of the Darrehanjir-Mashhad "ophiolites", NE Iran. Gondwana Research, doi: 10.1016/j.gr.2014.06.009

Shahabpour, J. 2005: Tectonic evolution of the orogenic belt in the region located between Kerman and Neyriz. - Journal of Asian Earth Sciences, 24, pp. 405-417.

Sheikholeslami, M.R., A. Pique, P. Mobayen, M. Sabzehei, H. Bellon, M. Hashem Emami 2008: Tectono-metamorphic evolution of the Neyriz metamorphic complex, Quri-Kor-e-Sefid area (Sanandaj-Sirjan Zone, SW Iran). - Journal of Asian Earth Sciences, 31, pp. 504-521.

Sheikholeslami, M.R., M. Kouhpeyma 2012: Structural analysis and tectonic evolution of the eastern Binalud Mountains, NE Iran. - Journal of Geodynamics, 61, pp. 23-46.

Sosson, M., Y. Rolland, C. Muller, T. Danelian, R. Melkonyan, S. Kekelia, S. Adamia, V. Babazadeh, T. Kangarli, A. Avagyan, G. Galoyan, J. Mosar 2010: Subductions, obduction and collision in the Lesser Caucasus (Armenia, Azerbaijan, Georgia), new insights. - Geological Society, London, pp. 329-352.

Stampfli, G.M. 1978: Etud geologique generale de l'Elbourz oriental au sud de Gonbade Qabus, Iran NE. These. - Geneve, 329 pp.

Stampfli, G.M., G. Borel, W. Cavazza, J. Mosar, P.A. Ziegler 2001: The Paleotectonic atlas of the periTethyan domain. - In: CD-ROM, vol. 8. European Geophysical Union to Accompany periTethys.

Stampfli, G.M., C. Hochard 2009: Plate tectonics of the Alpine realm. - Geological Society, London Special Publications, 327, pp. 89-111.

Stern, R.J., P. Johnson 2010: Continental lithosphere of the Arabian Plate: A geologic, petrologic, and geophysical synthesis. - Earth-Science Reviews, 101, pp. 29-67.

Stöcklin, J. 1968: Structural history and tectonics of Iran; A review. - American Association of Petroleum Geologists Bulletin, 52, pp. 1229-1258.

Stöcklin, J. 1972: Iran Central, Septentrional et Oriental. Lexique stratigraphique International 3, Fasicule 9b, Iran. - Centre National de la Recheche Scientifique, Paris, pp. 1-283,

Sudi Ajirlu, M., A. Jahangiri 2010a: Petrography and tectonic setting of Allahyarlu ophiolite. $-21^{\text {st }}$ Congress of Geological Sciences, Geological Survey of Iran (In Persian).

Sudi Ajirlu, M., A. Jahangiri, M. Moayyed 2010b: Relative dating of Allahyarlu ophiolite emplacement based on dating of limestones in core of Allahyarlu anticline, NW Iran. $-5^{\text {th }}$ Iranian Congress of Paleontology, Environmental Science Research Center, Kerman (In Persian).

Tirrul, R., I.R. Bell, R.J. Griffis, V.E. Camp 1983: The Sistan suture zone of eastern Iran. - Geol. Soc. Am. Bull., 94, pp. 134-150.

Wilmsen, M., F.T. Fürsich, J. Taheri 2009: The Shemshak Group (Lower-Middle Jurassic) of the Binalud Mountains, NE Iran: Stratigraphy, facies and geodynamic implications. - In: Brunet, M.F., M. Wilmsen, J.W. Granath (Eds): South Caspian to Central Iran Basins. The Geological Society, London, Special Publications, 312, pp. 175-188. 
Withjack, M.O., R.W. Schlische, P.E. Olsen 1998: Diachronous rifting, drifting, and inversion on the passive margin of central eastern North America: An analog for other passive margins. - American Association of Petroleum Geologists Bulletin, 82, pp. 817-835.

Zakariadze, G.S., Y. Dilek, S.M. Adamia, R.S. Oberhansli, S.M. Karpenko, B.A. Bazylev, N. Soloveva 2007: Geochemistry and geochronology of the Neoproterozoic Pan-African Transcaucasian Massif (Republic of Georgia) and implications for island arc evolution of the late Precambrian Arabian-Nubian Shield. - Gondwana Research, 11, pp. 92-108.

Zanchetta, S., A. Zanchi, I. Villa, S. Poli, G. Muttoni 2009: The Shanderman eclogites: A Late Carboniferous high-pressure event in the NW Talesh Mountains (NW Iran). - Geological Society, London, Special Publications, 312. pp. 57-78.

Zanchi, A., F. Berra, M. Mattei, M.R. Ghassemi, J. Sabouri 2006: Inversion tectonics in central Alborz, Iran. - Journal of Structural Geology, 11, pp. 2023-2037.

Zarrinkoub, M.H., S.L. Chung, H.Y. Chiu, S. Mohammadi, M. Khatib, I.J. Lin 2010: Zircon U-Pb age and geochemical constraints from the northern Sistan suture zone on the Neotethyan magmatic and tectonic evolution in eastern Iran. - Abst. To GSA Conference on "Tectonic Crossroads: Evolving Orogens in Eurasia-Africa-Arabia", Oct. 4-8, 2010, Ankara, Turkey.

Zarrinkoub, M.H., K.N. Pang, S.L. Chung, M.M. Khatib, S.S. Mohammadi, H.Y. Chiu, H.Y. Lee 2012 Zircon $\mathrm{U}-\mathrm{Pb}$ age and geochemical constraints on the origin of the Birjand ophiolite, Sistan suture zone, eastern Iran. - Lithos-02807; 14 pp.

Zonenshain, L.P., X. Le Pichon 1986: Deep basin of the Black Sea and Caspian Sea as remnants of Mesozoic back-arc basins. - Tectonophysics, 124, pp. 181-211. 